\title{
Article
}

\section{The Impact of Green Finance on Urban Haze Pollution in China: A Technological Innovation Perspective}

\author{
Yiting Zeng ${ }^{1}$, Feng Wang ${ }^{1,2} \mathbb{D}$ and Jun $\mathrm{Wu}^{1, *(\mathbb{D})}$ \\ 1 School of Economics and Business Administration, Chongqing University, Chongqing 400030, China; \\ candice_yiting@163.com (Y.Z.); wangfeng2008@cqu.edu.cn (F.W.) \\ 2 Institution of Energy Economics, Chongqing University, Chongqing 400030, China \\ * Correspondence: wujun@cqu.edu.cn
}

Citation: Zeng, Y.; Wang, F.; Wu, J. The Impact of Green Finance on Urban Haze Pollution in China: A Technological Innovation Perspective. Energies 2022, 15, 801. https:// doi.org/10.3390/en15030801

Academic Editor: Periklis Gogas

Received: 19 December 2021

Accepted: 18 January 2022

Published: 22 January 2022

Publisher's Note: MDPI stays neutral with regard to jurisdictional claims in published maps and institutional affiliations.

Copyright: (C) 2022 by the authors. Licensee MDPI, Basel, Switzerland. This article is an open access article distributed under the terms and conditions of the Creative Commons Attribution (CC BY) license (https:// creativecommons.org/licenses/by/ $4.0 /)$.

\begin{abstract}
Green finance integrates the concept of environmental governance into the financial industry, which is conducive to sustainable development. Applying the mediating effect model, this paper investigates the effect of green finance on urban haze pollution and explores the mediating role of technological innovation of enterprises between them. Based on a sample of 639 enterprises in China over 2016-2019, a significantly negative effect of green finance on urban haze pollution is found. An increase of one standard deviation in green finance decreases PM2.5 concentration by $8.8 \mu \mathrm{g} / \mathrm{m}^{3}$, ceteris paribus. Further, green finance may improve environmental quality by promoting technological innovation. Considering the heterogeneity of enterprise ownership, this mediating effect exists in non-state-owned enterprises, while it cannot be observed in state-owned enterprises. This study proposes a new solution for pollution: using green financial tools to promote environmentally friendly technological progress.
\end{abstract}

Keywords: green finance; haze pollution; technological innovation; enterprise ownership

\section{Introduction}

Since the reform and opening-up, China's economy has made remarkable achievements. However, the development mode of high pollution and high energy consumption has brought environmental pollution and ecological damage, especially the air pollution represented by haze, which has a serious impact on human life due to its severe health hazards and long duration. The Air Pollution Prevention and Control Action Plan, issued by the State Council in 2013, stipulates that by 2017, the concentration of inhalable particles in cities above prefecture level in China must be $10 \%$ lower than that in 2012 . However, resource-intensive and labor-intensive products are the main driving forces of China's rapid economic growth, which exacerbates resource scarcity and environmental degradation [1]. To mitigate the intense relationship between environment and finance, green finance is considered to be an intersection between environmentally behavior and the financial and business world [2].

In July 2016, the Standing Committee of the National People's Congress passed the amendment of Law of the People's Republic of China on Conserving Energy, clearly proposing that the government departments should guide financial institutions to increase credit support for energy-saving projects and provide preferential loans for qualified projects such as energy-saving technology research and development, energy-saving new product production and energy-saving technological transformation. Under the guidance of such policies, China's green credit, green bonds, green venture capital funds and green stock index have developed rapidly [3].

Green finance can not only solve haze pollution problems, but also improve the technology innovation of enterprises. The technology innovation of enterprises is always hindered by financing constraints because of high uncertainty and low return. However, 
green finance policies can significantly improve technology innovation capabilities by alleviating financing constraints faced by enterprises [4]. Furthermore, improving technology innovation can improve the efficiency of energy use, which can also play a role in preventing haze pollution [5]. In this context, it is of great theoretical and practical significance to study the impact of green finance and technology innovation on regional haze governance in the background of China's major strategy of building an innovative country and launching a pollution control battle.

However, there are a series of problems remaining to be solved. Whether, how and to what extent does green finance affect enterprise technology innovation? Whether and how does enterprise technology innovation effectively reduce haze pollution? Whether and to what extent does enterprise technology innovation serve as the mediator between green finance and haze pollution?

In answering the above questions, this study makes contributions in two aspects. First, this paper introduces a new micro perspective of enterprise technology innovation and explores the mechanism of how green finance influences haze pollution and verifies the mediation role of enterprise innovation technology, while the existing research mainly focuses on the macro level. The results show that the partly mediating role of innovation output between green finance and haze pollution, while the mediating role of innovation input is not found. Second, we analyze the heterogeneity of the mediation role of technological innovation from the perspective of the nature of enterprise ownership. This paper finds that state-owned enterprises do not perform as well as non-state-owned enterprises, and state-owned enterprises should be more socially responsible in environmental protection.

The remainder of this article is organized as follows: Section 2 reviews the literature, Section 3 develops the theoretical hypotheses, Section 4 introduces the methodological issues and data used in the analysis, Section 5 provides empirical results and discussion, and Section 6 concludes and presents policy implications.

\section{Literature Review}

\subsection{Green Finance}

As the country's attention to environmental protection and sustainable development has increased, 'green finance' as a new research field of financial industry has emerged. Prior to 1990, many scholars believed that financial investment and financing only indirectly influenced the environment through the process of 'production and consumption-natural environment-production and consumption' as exogenous variables. With the continuous change of the concept of environmental protection, the foreign financial industry has been put into practice to adapt to the sustainable development strategy of enterprises, among which the most influential is the financial self-discipline organization organized by the United Nations Environment Programme. At the same time, domestic scholars such as Yu \& Guo also put forward that financial activities are closely related to the natural environment, and the financial industry is of great significance to the sustainable development of the country [6]. Since the 21st century, many domestic scholars have studied the theory and social practice of foreign environment. In view of the increasingly serious environmental problems and the single financing channel of environmental industries, scholars begin to think over how to protect the environment from the factors of financial induction. The continuous deepening of domestic scholars' research on environmental finance and the proposal of the term 'circular economy' have also spawned relevant research on the green finance in China [7-9].

There is no internationally recognized definition of the term green finance. The concept of 'environmental finance' first appeared in foreign countries. Salazar believed that environmental finance is a financial innovation carried out by the financial industry to meet the financing needs of the environmental protection industry [10]. Based on this, the American Heritage Dictionary defines 'Green Finance' as 'Environmental Finance' or 'Sustainable Financing'. 
An combined the definitions of green finance based on different macro and micro research perspectives, and summarized the green finance as the effort of the financial industry to alleviate environmental pollution for the purpose of reform and innovation of credit, insurance, securities and derivatives, followed by industrial development induction and macro policy regulation [11].

In 2016, the People's Bank of China defined green finance as financial services to provide investment and financing, project operation, risk management and other projects in the fields of environmental protection, energy conservation, clean energy, green transportation and green buildings. According to this definition, the financial assets of the social green economy are roughly divided into three categories: green credit assets, green bond assets and green insurance assets. The development of green finance is urgent in China and is conducive to the adjustment of its industrial structure and the coordinated growth of regions [12]. He et al. find that when green credits exceed 1.468 billion yuan, they are conducive to investment in renewable energy and growth of the green economy [13].

At present, the research on green finance in China has gradually increased, mainly focusing on the concept connotation, overseas experience, development mode and policy system. Environmental governance effects of green finance are rarely involved.

\subsection{Green Finance and Haze Pollution}

The research on haze pollution mainly focuses on the economic consequences and influencing factors of haze pollution. Economic consequences mainly focus on macroeconomic and micro-level impact. At the macro level, Dong et al. found that in areas with high haze pollution, local industrial agglomeration and industrial efficiency are greatly limited, which further affects the local economic benefits [14]. The micro level is reflected in the impact on corporate stock returns, earnings management, corporate value, debt financing and corporate innovation [15-20]. Based on the fixed effect model, Zhang et al. found that haze pollution has a positive impact on corporate social environmental responsibility, and business performance plays a regulatory role [21].

The formation factors of haze pollution are mainly reflected in three aspects: (1) Technical structural factors: Leng and Du based on China's 2001-2010 provincial PM2.5 panel data empirical research, found that industrial structure is the influencing factor of haze pollution [22]. Liufound that technological innovation can reduce haze pollution and indirectly reduce the haze concentration of neighboring provinces through the knowledge spillover effect [23]. (2) Economic factors: Zhang et al. examined the effect of high-speed rail accessibility on haze pollution, and found a new solution for pollution, that improving air quality through intercity transport efficiency enhancement [24]. Wang et al. found the foreign direct investment aggravate haze pollution, but fiscal decentralization can weaken this effect [25]. (3) Governmental factors: Many scholars pay attention to the influence of the interaction effect of local governments. In terms of policy effect, Chen et al. studied the current policy of the Beijing Olympic Games and found that the current policy improved air quality [26].

The development of the green finance promotes the haze governance industry. After the introduction of the concept of 'green investment', a large number of industrial capital inflows, so the market needs to guide, regulate and use capital to boost reliable technical projects [27]. Haze control industry is a new industry centered on solving haze problems, which is a concentrated reflection of green economy throughout various emerging industries such as energy saving, environmental protection, new energy and ecological agriculture. In 2016, China implemented the regulations on 'air pollution control' and guided specific industries to link with professional technology, so as to closely integrate the haze remediation industry and the green financial industry, and create more new and efficient channels of haze governance. 
At present, research on green finance and haze pollution in China and abroad is not sufficient, but it preliminarily shows the relationship between green finance and environmental pollution. For example, Shahbaz et al. believed that the structural effect of carbon emissions can be reduced through investment and financing support for the research and development practice of clean technology [28]. Li, Yuan, et al. measured the coupling and coordination degrees between green finance and ecological environment in the three economic circles of the Yangtze River Delta, the Pearl River Delta and Beijing-Tianjin-Hebei [29]. Liu and Wen creatively discuss the environmental responsibility of financial institutions in the framework of the classical economic growth theory and provide new ideas for the research of green finance. Based on the vector error model [30]. Ren et al. find that the implementation of green finance can reduce carbon intensity [31]. Zhu et al. incorporated green finance into the analytical framework of environmental regulation to explore how the interaction between green finance and environmental regulation, industrial structure and technological level affects haze governance [5]. Through the analysis of the Spatial Dubin Model, it is found that green finance can cooperate with environmental regulation, the structural effect and the technical effect to enhance the haze governance effect. The technical effect is stronger than the environmental regulation and the structural effect. Moreover, in the pollution governance mechanisms there are differences and a strong complementarity between green finance and environmental regulation. Green finance plays an important role in the development of haze control industries in different regions.

\subsection{Green Finance, Enterprise Technology Innovation and Haze Pollution}

Green finance is a financial innovation based on environmental protection [10]. It can provide financial services such as investment and financing, project operation and risk management for enterprises in various environmental protection fields. The mechanism of green finance to improve the innovation ability of enterprises mainly functions in two aspects. On the one hand, it provides funds for enterprises to solve the capital constraints. On the other hand, the issuance of green credit depends on the assessment of the environmental protection qualification of enterprises. Therefore, external supervision is also introduced, including government supervision and media supervision, which can restrain the environmental pollution behavior of enterprises, urge enterprises to carry out environmental innovation and transformation, and further improve the innovation ability of enterprises [32].

Foreign and domestic research on the impact of green finance on enterprise innovation ability is deepening. Schumpeter first proposed the concept of 'innovation' [33]. Technological innovation aiming at creating new technologies can help enterprises gain more profit and resource support, but achieving the goal of innovation requires sufficient financial support. Porter put forward the 'Potter hypothesis' that the strengthening of environmental regulation can stimulate enterprises to increase innovation investment, so as to improve output, thereby offset the cost of environmental regulation, which can then improve the market competitiveness of enterprises in the long term [34]. Therefore, when green finance introduces external environmental supervision to enterprises according to Potter hypothesis, enterprises will strengthen enterprise innovation in order to broaden green financing channels and achieve environmental standards to better attract green investment. At the same time, Lanoie et al. mentioned in his findings that performance standards induce innovation by giving firms the incentive to find the best way to reduce their environmental impact [35]. In addition, Hong et al. used the difference-in-difference method to study the impact of green credit on green technology innovation of enterprises [36]. The results show that green credit has a leading role in promoting green technology innovation of enterprises, and clarifies the mechanism of green credit on green technology innovation of enterprises. It states that public attention may be attracted to green products by the green credit policy, which makes enterprises have to face public supervision, pay more attention to their social responsibility and initiatively improve the level of green technology innovation. 
Meng and Yan pointed out that green finance promotes the optimization of enterprise ecological innovation investment structure by alleviating the tight financing of enterprise innovation and adjusting and maintaining the profit right of green asset transactions through the development of green finance primary and secondary markets [37]. Qiu et al. measured the degree of regional green financial development by constructing an evaluation index system of China's green financial development level and used it as an explanatory variable to construct a negative binomial model to study the impact of green financial development on innovation performance [32]. The conclusion was that the improvement of green development level could lead to the reduction of unit R\&D investment and the improvement of innovation output, so the development of green finance is helpful to the improvement of enterprise innovation ability. The above literatures found that the development of green finance can significantly improve the technological innovation ability of enterprises.

At the same time, the technological innovation of enterprises is also closely related to haze pollution. Grossman and Krueger believed that the 'technological effect' is one of the factors affecting the environment, and technological progress can significantly improve environmental pollution [38]. Chiou et al. used enterprise data to study the impact of innovation on environmental performance and believed that green technology innovation can significantly improve environmental conditions [39]. Yuan and Rong used provincial panel data to analyze the impact of technological innovation on environmental pollution in the process of industrial agglomeration. The results showed that technological innovation could significantly improve environmental conditions [40]. Cheng et al. found that the haze emission reduction effect of technical efficiency improvement is stronger, while the promotion of scientific and technological progress on haze emission reduction is relatively weak [41]. Using the CGE model, Wei and Ma found that energy clean technology progress will reduce emissions per unit energy consumption and alleviate air pollution [42]. Lu and Bai used dynamic panel space and dynamic panel threshold to verify that green technology innovation can affect haze pollution [43].

The main shortcomings of the existing researches are reflected in the following aspects. The empirical researches studied either the relationship between the development of green finance and haze pollution, or the relationship between the innovation ability of enterprises and haze pollution. In the study of the mechanism of green finance affecting haze pollution, it was also mainly conducted from a macro perspective. For example, green finance affected haze pollution through environmental regulation, industrial structure and technological level [5]. Few researches discussed the three factors in a unified framework, green finance, enterprise technological innovation and haze pollution. Few studies have focused on the influence of macro financial systems, micro enterprise behavior and the external environment. However, combined with the existing literature, it can be known that green finance can promote enterprise technological innovation by alleviating capital constraints and improving external supervision, while enterprise technological innovation can reduce local haze pollution through efficient resource utilization and cleaner production. Therefore, this paper attempts to introduce the factor of enterprise technological innovation from the perspective of micro-mechanism of action at the empirical level to verify that enterprise technological innovation is the intermediary variable between green finance and haze pollution.

\section{Theoretical Analysis and Research Hypotheses}

\subsection{The Relationship between Green Finance and Haze Pollution}

Green finance mainly reduces the degree of haze pollution by optimizing the industrial structure. Firstly, strict environmental information disclosure and capital regulation of green finance have increased the financing cost of polluting enterprises. Lian stated that green finance has raised the cost of debt financing for companies with high pollution and energy consumption [44]. Su and Lian found that green finance policies significantly reduced interest-bearing debt financing and long-term liabilities of heavily polluting en- 
terprises and new investments [45]. Secondly, green finance encourages the development of green industries including clean energy, rail transit and new materials [5]. Different from the environmental regulation, which directly limits the development of polluting industries by setting access and emission standards in a command-and-control manner, green finance mainly increases the return of clean industries, enhances green financial markets and forms a virtuous cycle of capital by means of green industry cultivation and capital regulation [46]. Relevant researches show that green finance encourages enterprises to invest in clean technology. Therefore, in the process of reducing pollution industries and increasing green industries, green finance improves the industrial structure and effectively reduces the degree of haze pollution in the region. Therefore, the following hypothesis is proposed:

Hypothesis H1. Green finance can significantly reduce the degree of haze pollution in a region.

\subsection{The Relationship between Green Finance and Enterprise Technology Innovation}

Regarding enterprise technology innovation, the academic measurement of this index is usually carried out in two dimensions: enterprise innovation input and enterprise innovation output. R\&D expenditure symbolizes the degree of R\&D efforts of enterprises. R\&D expenditure is generally continuous, which is helpful to the allocation of innovative resources and may directly affect the technological innovation ability of enterprises. Patent output, as the innovation achievements of enterprises, is used to characterize the innovation output of enterprises, which can best illustrate the effectiveness of enterprises in innovation.

Based on the research of Meng and Yan [37], this paper argues that green finance can affect the matching of the risk and income of innovation behavior by allocating capital and influencing the expected income structure of innovation behavior, so as to guide enterprises to choose technological innovation behavior.

First of all, from the perspective of financing capital: due to the characteristics of large amount of investment, high risk and long cycle of enterprise technology innovation, enterprise technology innovation is facing greater uncertainty [47-50], and the enterprise is with a low risk tolerance to debt capital, so ordinary financial institutions are not willing to invest in enterprise innovation projects, which leads to the high cost of enterprise financing. Green finance aims to allocate capital through financial measures and guide capital to flow to the field of environmental protection. It takes the environmental compliance of enterprises as an important condition for the issuance of loans. Therefore, if enterprises meet the environmental protection standards of local green finance, it is easier to obtain financing, which can effectively improve financing efficiency, reduce financing costs and improve the availability of funds. He et al. analyzed 152 environmental listed companies in China, and found that green finance encourages R\&D investment and promotes technological innovation [51].

Secondly, from the perspective of the expected return structure of innovation behavior: Porter puts forward the 'innovation compensation effect' [34]. That is, in the background of the rising requirements for green development, an enterprise can improve its income in order to offset the cost of environmental governance by increasing technological innovation, then reducing pollution emissions, which leads to lower environmental taxes and fees. However, Li et al. pointed out that environmental pollution has a negative 'offset effect' on technological innovation [16]. When enterprises face the environmental regulation in the background of green financial development, their internal pollution control cost and external pollution prevention cost will increase. The increase of cost will squeeze the innovation funds of enterprises, which makes it impossible for enterprises to invest heavily in technological innovation activities. Instead, they can focus only on the end-of-pipe treatments to deal with haze pollution. However, with the continuous development of green finance, enterprises are facing stronger financing pressure, external public opinion pressure and moral condemnation. For instance, commercial banks strictly control green credit issuance, pay more attention to corporate environmental compliance and improve 
the standards for corporate environmental protection requirements, while the government and the financial sector require a comprehensive grasp of the environmental information of enterprises and the disclosure requirements of enterprise environmental information continue to be strict. More attention is continuously paid to the environmental protection and sustainable development ability of enterprises. In order to win a position in the field where environmental protection concept is strengthened, enterprises must fundamentally prevent and control their pollution. The most fundamental way to solve this problem is technological innovation, rather than end-of-pipe governance. This economic lever guides enterprises to internalize pollution costs, so as to achieve beforehand treatment, rather than afterwards pollution control. Therefore, in the contemporary era of green finance development, it is considered that the 'innovation compensation effect' is greater than the 'offset effect', and enterprises have greater benefits through technological innovation. Therefore, the following hypotheses are established:

Hypothesis H2a. The development of green finance helps to improve enterprise innovation output.

Hypothesis $\mathbf{H} \mathbf{2 b}$. The development of green finance helps to improve enterprise innovation input.

\subsection{The Relationship between Green Finance, Enterprise Technology Innovation and Haze Pollution}

Enterprises' technological innovation driven by green finance can reduce regional haze pollution. At first, referring to Chen et al. enterprises carry out technological innovation with the support of green finance, which can reduce environmental pollution through energy conservation [52]. Specifically, it is a general way to save energy and reduce consumption that enterprises carry out technological transformation of equipment with large energy consumption or use funds to purchase higher quality equipment from the outside in order to achieve high efficiency and low consumption. At the same time, technological innovation can save relatively expensive production factors, thereby reducing the cost of energy use [53]. Using energy efficiently and reducing energy consumption are bound to reduce waste emissions from enterprises and haze pollution.

Secondly, technological innovation will bring a crowding out effect to pollution enterprises. With the development of green finance, material capital elements are increasingly gathering to environmental-friendly enterprises. It is difficult for polluting enterprises to obtain capital elements, because it has become in a competitive disadvantage. The technological innovation of environmental protection enterprises brings innovative products, which will lead to changes in the consumer market. The improvement of consumers' awareness of environmental protection gives environmental protection products a competitive advantage, and eliminates or limits enterprises with insufficient technological innovation capability and enterprises with serious pollution. Therefore, in order not to be excluded, enterprises attach great importance to technology innovation to control regional haze pollution.

In summary, this paper argues that, on the one hand, green finance can directly affect the haze pollution; on the other hand, green finance can have a positive impact on enterprise technology innovation, and enterprise technology innovation can also reduce regional haze pollution to a certain extent. Therefore, through the process of green finance (external market) - enterprise technology innovation (enterprise behavior) - haze pollution (external environment), the degree of regional haze pollution can be finally reduced. Therefore, the following hypotheses are proposed: 
Hypothesis H3a. Enterprise innovation output takes a partial mediating effect between green finance and haze pollution.

Hypothesis H3b. Enterprise innovation input takes a partial mediating effect between green finance and haze pollution.

\section{Research Method}

4.1. Variables and Data Description

\subsubsection{Haze Pollution}

According Zhang et al. [54], the annual average concentration of fine particles with a diameter of $2.5 \mu \mathrm{m}$ or less (PM2.5) is employed as the proxy indicator of cities' haze pollution. The data are from the Environmental Monitoring Station (CNEMC, 2021). Referring to the practice of previous scholars, the robustness test uses PM10 as the proxy variable of haze pollution.

\subsubsection{Green Finance}

Following Meo and Abd Karim [55], this paper adopts urban green bond as a proxy of green finance $(G F)$. Green bonds are long-term financial instruments in which the proceeds from green bonds are used solely for financial projects that are environmentally friendly or reduce pollution in the environment. Taking into account the maturity and cumulative effect of green bonds, the $G F_{i t}$ is obtained by adding all bond amounts in urban green bonds that have a maturity of $t$ year. The main reasons for using the issuance of urban green bonds as green financial proxy indicators are as follows: First, compared with green credit, green insurance, carbon finance and other products, the issuers of green bonds are mainly financial institutions and enterprises, which can reflect the real level of local green finance. Second, this paper studies the mediating effect of corporate innovation, and the limitation of green bond issuers is conducive to exploring the real impact of green finance on corporate debt financing. Third, from the perspective of data availability, green bond information is complete and can meet the analysis needs. Green bond data are from the Wind database.

\subsubsection{Innovation Performance}

This paper plans to start from the two dimensions, innovation input and innovation output. The proportion of R\&D investment in operating income is used as the proxy variable of innovation input, and the patent authorization quantity is used as proxy variable of innovation output, INNO-IN and INNO-OUT, respectively. The data of R\&D investment amount and patent authorization quantity come from the CSMAR database.

\subsubsection{Control Variables}

This paper selects control variables at the enterprise level and the city level. According to Li et al. [56], the enterprise level control variables include the size of the corporate (SIZE), profitability $(R O A)$, growth ability $(G R O W)$, the proportion of independent directors $(O D R)$, duality of COB and CEO (DUAL) and the nature of property rights (SOE). Urban level control variables include: urban economic growth rate $(E I)$ and urban gross industrial output value (GVIO). It is generally believed that the higher the level of urban industrial development, the more serious the haze pollution in the region. Moreover, it is believed that the faster the economic growth of a city, the greater the consumption of various production factors, such as energy, and the stronger the impact on haze pollution. All variables are listed and explained in Table 1. The above data are from CSMAR and Wind databases. 
Table 1. Variable definitions and data sources.

\begin{tabular}{|c|c|c|c|}
\hline Variable & Definition & Measurement & Data Sources \\
\hline$P M_{2.5}$ & Haze pollution & $\begin{array}{l}\text { Annual concentration of urban } \\
\text { PM2.5 }\end{array}$ & $\begin{array}{l}\text { Environmenta } \\
\text { Monitoring } \\
\text { Station }\end{array}$ \\
\hline$P M_{10}$ & Haze pollution & $\begin{array}{l}\text { Annual concentration of urban } \\
\text { PM10 }\end{array}$ & $\begin{array}{l}\text { Environmenta } \\
\text { Monitoring } \\
\text { Station }\end{array}$ \\
\hline GF & Green finance & $\begin{array}{l}\text { Characterized by the size of } \\
\text { city-owned green bonds. GF it is } \\
\text { obtained by summing up all } \\
\text { bonds in city-owned green } \\
\text { bonds with a maturity of } t \text { year }\end{array}$ & Wind \\
\hline INNO-OUT & Innovation output & Patent authorization quantity & CSMAR \\
\hline INNO-IN & Innovation input & $\begin{array}{l}\text { R \& D investment divided by } \\
\text { operating income }\end{array}$ & CSMAR \\
\hline SIZE & $\begin{array}{l}\text { The size of } \\
\text { the corporate }\end{array}$ & $\begin{array}{l}\text { The natural logarithm of the total } \\
\text { assets at the end of the year }\end{array}$ & CSMAR \\
\hline$R O A$ & Profitability & Net profit divided by total assets & CSMAR \\
\hline GROW & $\begin{array}{l}\text { (Current year operating } \\
\text { profit-previous year } \\
\text { operating } \\
\text { profit)/previous year } \\
\text { operating profit }\end{array}$ & Growth ability & CSMAR \\
\hline$O D R$ & $\begin{array}{l}\text { The proportion of } \\
\text { independent directors }\end{array}$ & $\begin{array}{l}\text { Number of independent } \\
\text { directors divided by number of } \\
\text { directors }\end{array}$ & CSMAR \\
\hline$D U A L$ & Duality of COB and CEO & $\begin{array}{l}1 \text { for the same person as the } \\
\text { chairman and general manager } \\
\text { and } 0 \text { for different } \\
\text { persons as the Chairman and } \\
\text { the General Manager }\end{array}$ & CSMAR \\
\hline$S O E$ & $\begin{array}{c}\text { Nature of } \\
\text { property right }\end{array}$ & $\begin{array}{c}1 \text { for State-owned enterprises } \\
\text { and } 0 \text { for non-state-owned } \\
\text { enterprises }\end{array}$ & CSMAR \\
\hline$E I$ & $\begin{array}{l}\text { Urban economic growth } \\
\text { rate }\end{array}$ & Urban GDP growth rate & CSMAR \\
\hline GVIO & $\begin{array}{l}\text { Urban gross industrial } \\
\text { output value }\end{array}$ & $\begin{array}{c}\text { Urban gross industrial output } \\
\text { value }\end{array}$ & CSMAR \\
\hline
\end{tabular}

\subsection{Sample Selection}

This paper takes all A-share listed companies on the main board of Shanghai and Shenzhen Stock Exchanges from 2016 to 2019 as the research sample. In the process of data processing, the data of ST and $\mathrm{ST}^{*}$ companies and listed companies with a serious lack of relevant variables are eliminated. Finally, the sample includes 639 listed companies, and the total observation value is 1181. Taking 2016-2019 as the research period, there are the following reasons. 2016 is the first year of China's green finance. With the release of the article 'Guidelines for Establishing the Green Financial System', China's green finance ushered in rapid development. From 2016 to 2019, China's environmental governance has achieved remarkable results, and the statistical data tend to be perfect, which facilitates the development of research [5]. Financial data of listed companies are from CSMAR and Wind database. 


\subsection{Model Specification}

To initially verify the mediating role of innovation in the relationships between green finance and haze pollution in China, referring to Wen and Ye on the mediating effect test [57], this paper has constructed the following model:

$$
\begin{gathered}
\text { PM2.5 } 5_{i t}=\alpha_{0}+\alpha_{1} G F_{i t}+\alpha_{2} X_{i t}+\lambda_{i}+\mu_{t}+\varepsilon_{i t} \\
I N N O_{i t}=\beta_{0}+\beta_{1} G F_{i t}+\beta_{2} X_{i t}+\theta_{i t} \\
P M 2.5_{i t}=\gamma_{0}+\gamma_{1} G F_{i t}+\gamma_{2} I N N O_{i t}+\gamma_{3} X_{i t}+\lambda_{i}^{\prime \prime}+\mu_{t}^{\prime \prime}+\delta_{i t}
\end{gathered}
$$

where the parameter $X_{i t}$ denotes a vector of control variables. $\alpha, \beta$ and $\gamma$ denote the corresponding coefficients. $\lambda_{i}$ and $\mu_{t}$ represent the company-fixed effect and the time-fixed effect, respectively. $\varepsilon_{i t}, \theta_{i t}$ and $\delta_{i t}$ represent the random errors.

\section{Empirical Results and Discussion}

\subsection{Descriptive Statistics}

The main purpose of using descriptive analysis is to describe the basic features of the data in this study. Through the descriptive statistics (Table 2) analysis of the samples, it is found that the average concentration of PM2.5 is 42.08 , which belongs to good air quality grade $\left(35-75 \mu \mathrm{g} / \mathrm{m}^{3}\right)$. The standard deviation of PM2.5 variable is large, indicating that the degree of haze pollution in cities is different. The average value of the development level of green finance is 332.6 , the maximum value is 2077 , the minimum value is only 1.640 , and the variance is 488.5 , indicating that the development of green finance varies greatly among regions, and the overall level is not high, which may result from that China's practice of advocating the development of green finance is in its infancy. The maximum value of enterprise innovation output is 4434 , the minimum value is 0 , and the average value is 119.3. The listed companies studied have an average of 119.3 patent authorizations during the research period, while the number of enterprises with the largest number of patent authorizations is 4434 a year, indicating that the overall level of innovation of enterprises shows an upward trend, and new patents are generated every year. The variance of innovation output reaches 387.4, indicating that the level of innovation output between enterprises fluctuates greatly, which may be due to the large difference in research funds, scientific research personnel and other resources owned by enterprises. In addition, the level of enterprise innovation input reaches $5.805 \%$, the maximum value is $54.65 \%$ and the minimum value is $0.0 \%$, indicating that $5.805 \%$ of the operating income of each unit is used for R\&D. Some companies have not conducted R\&D during the sample period.

Table 2. Summary statistics of variables.

\begin{tabular}{cccccc}
\hline & $\mathbf{( 1 )}$ & $\mathbf{( 2 )}$ & $\mathbf{( 3 )}$ & $\mathbf{( 4 )}$ & $\mathbf{( 5 )}$ \\
\hline Variable & $\mathbf{N}$ & Mean & $\mathbf{s d}$ & Min & Max \\
\hline PM2.5 & 1181 & 42.08 & 11.32 & 17 & 74 \\
PM1O $_{i t}$ & 1181 & 66.02 & 16.63 & 32 & 135 \\
FF $_{i t}$ & 1181 & 332.6 & 488.5 & 1.640 & 2077 \\
$I N N O-O U T_{i t}$ & 1181 & 119.3 & 387.4 & 0 & 4434 \\
$I N N O-I N_{i t}$ & 1181 & 5.805 & 5.333 & 0 & 54.65 \\
SIZE & 1181 & 22.32 & 1.483 & 19.40 & 28.19 \\
OOA $_{i t}$ & 1181 & 0.0410 & 0.0838 & -1.648 & 0.289 \\
GROW $_{i t}$ & 1181 & 0.00671 & 0.00658 & -0.0250 & 0.00864 \\
ODR $_{i t}$ & 1181 & 0.378 & 0.0559 & 0.250 & 0.750 \\
DUAL $_{i t}$ & 1181 & 0.299 & 0.458 & 0 & 1 \\
SOE $_{i t}$ & 1181 & 0.124 & 0.330 & 0 & 1 \\
I I $_{i t}$ & 1017 & 0.0977 & 0.0409 & -0.130 & 0.285 \\
GVIO $_{i t}$ & 1006 & $1.479 \times 10^{8}$ & $1.314 \times 10^{8}$ & 0 & $3.484 \times 10^{8}$ \\
\hline
\end{tabular}


Table 3 reports the unit root test results of PM2.5 and PM10 to address the concern of integrated of order $0(\mathrm{I}(0))$. For the panel data in only 4 years, Harris-Tzavalis unit-root test with z-statistic and Im-Pesaran-Shin unit-root test with t-bar statistic have been used [58,59]. These tests show that the empirical research of this paper will not be troubled by the unit root and spurious regression [60].

Table 3. Unit root test for key variables.

\begin{tabular}{ccc}
\hline Variable & $\begin{array}{c}\text { Harris-Tzavalis Unit-Root Test } \\
\text { z-Statistic }\end{array}$ & $\begin{array}{c}\text { Im-Pesaran-Shin Unit-Root Test } \\
\text { t-Bar }\end{array}$ \\
\hline PM2.5 $5_{\text {it }}^{* * *}$ & $-3.0635^{* * *}$ & $-3.0375^{* * *}$ \\
$P M 10_{i t}^{* * *}$ & $-2.9858^{* * *}$ & $-7.1068^{* * *}$ \\
\hline
\end{tabular}

Notes: Robust t-statistics in parentheses. ${ }^{* * *} p<0.01,{ }^{* *} p<0.05,{ }^{*} p<0.1$.

\subsection{Analysis of the Basic Regression Results}

This paper is mainly based on the mediating effect model. Table 4 reports the basic regression results. Model (1) examines the total effect of green finance on haze pollution, and model (2) and model (3) further examine the mediating role of green finance in the process of haze pollution in areas affected by technological innovation. According to the Hausman test, model (1) and model (3) are the regression results of the two-way fixed effects model, and model (2) is the regression result of the mixed effects model.

From the regression results of model (1), the coefficient of GF is in line with expectations. An increase of one standard deviation in green finance (488.5) decreases PM2.5 concentration by $8.8 \mu \mathrm{g} / \mathrm{m}^{3}(-8.8=488.5 \times(-0.018))$. These estimated results mean that the higher the level of regional green finance development, the more regional haze pollution it can inhibit. The test results verify H1. From the regression results of the control variables, the regression coefficient of the total industrial output value (GVIO) in the region is significantly positive, which is also in line with expectations. The more developed the regional industry, the greater the emission of industrial smoke and dust and the more pollution particles generated by industrial waste incineration, which will all aggravate the haze pollution in the region.

Table 4. The basic regression results of mediating effect.

\begin{tabular}{|c|c|c|c|c|c|c|}
\hline & \multicolumn{3}{|c|}{ INNO-OUT $_{i t}$} & \multicolumn{3}{|c|}{$I N N O-I N_{i t}$} \\
\hline & (1) & (2) & (3) & (1) & (2) & (3) \\
\hline VARIABLES & PM2. $5_{i t}$ & $\begin{array}{l}\text { INNO- } \\
\mathrm{OUT}_{i t}\end{array}$ & PM2.5 & $P M 2.5_{i t}$ & $\begin{array}{c}I N N O- \\
I N_{i t}\end{array}$ & PM2.5 $5_{i t}$ \\
\hline $\begin{array}{c}G F_{i t} \\
I N N O- \\
O U T_{i t}\end{array}$ & $\begin{array}{c}-0.018^{* * *} \\
(-12.40)\end{array}$ & $\begin{array}{c}0.164^{* * *} \\
(3.02)\end{array}$ & $\begin{array}{c}-0.018^{* * *} \\
(-12.09) \\
-0.002^{* *} \\
(-2.14)\end{array}$ & $\begin{array}{c}-0.018^{* * *} \\
(-12.40)\end{array}$ & $\begin{array}{c}0.002 * * \\
(2.36)\end{array}$ & $\begin{array}{c}-0.018 \text { *** } \\
(-12.40)\end{array}$ \\
\hline$I N N O-I N_{i t}$ & & & & & & $\begin{array}{l}0.064 \\
(0.92)\end{array}$ \\
\hline$S I Z E_{i t}$ & $\begin{array}{l}-0.239 \\
(-0.39)\end{array}$ & $\begin{array}{c}136.173^{* * *} \\
(6.44)\end{array}$ & $\begin{array}{l}-0.159 \\
(-0.26)\end{array}$ & $\begin{array}{l}-0.239 \\
(-0.39)\end{array}$ & $\begin{array}{c}-1.206^{* * *} \\
(-11.07)\end{array}$ & $\begin{array}{l}-0.196 \\
(-0.32)\end{array}$ \\
\hline$R O A_{i t}$ & $\begin{array}{l}-1.267 \\
(-0.68)\end{array}$ & $\begin{array}{c}43.235 \\
(0.70)\end{array}$ & $\begin{array}{l}-1.077 \\
(-0.58)\end{array}$ & $\begin{array}{l}-1.267 \\
(-0.68)\end{array}$ & $\begin{array}{l}-1.570 \\
(-0.70)\end{array}$ & $\begin{array}{l}-0.922 \\
(-0.49)\end{array}$ \\
\hline $\mathrm{GROW}_{i t}$ & 15.766 & $\underset{* * *}{-3266.522}$ & 15.614 & 15.766 & 33.040 & 13.580 \\
\hline & $(0.74)$ & $(-3.46)$ & $(0.74)$ & $(0.74)$ & $(1.51)$ & $(0.64)$ \\
\hline
\end{tabular}


Table 4. Cont.

\begin{tabular}{|c|c|c|c|c|c|c|}
\hline & \multicolumn{3}{|c|}{ INNO-OUT $_{i t}$} & \multicolumn{3}{|c|}{$I N N O-I N_{i t}$} \\
\hline & (1) & (2) & (3) & (1) & (2) & (3) \\
\hline VARIABLES & PM2.5 & $\begin{array}{l}\text { INNO- } \\
\text { OUT }_{i t}\end{array}$ & PM2.5 & PM2.5 & $\begin{array}{c}\text { INNO- } \\
I N_{i t}\end{array}$ & PM2. $5_{i t}$ \\
\hline$O D R_{i t}$ & $\begin{array}{l}0.201 \\
(0.06)\end{array}$ & $\begin{array}{c}458.829 * * \\
(2.55)\end{array}$ & $\begin{array}{l}-0.310 \\
(-0.09)\end{array}$ & $\begin{array}{l}0.201 \\
(0.06)\end{array}$ & $\begin{array}{c}6.888^{* *} \\
(2.40)\end{array}$ & $\begin{array}{l}0.891 \\
(0.24)\end{array}$ \\
\hline$D U A L_{i t}$ & $\begin{array}{l}0.262 \\
(0.63)\end{array}$ & $\begin{array}{c}22.681 \\
(1.16)\end{array}$ & $\begin{array}{l}0.211 \\
(0.50)\end{array}$ & $\begin{array}{l}0.262 \\
(0.63)\end{array}$ & $\begin{array}{c}0.931^{* *} \\
(2.49)\end{array}$ & $\begin{array}{l}0.225 \\
(0.54)\end{array}$ \\
\hline$S O E_{i t}$ & $\begin{array}{l}-0.042 \\
(-0.08)\end{array}$ & $\begin{array}{c}-66.028 \\
(-1.58)\end{array}$ & $\begin{array}{l}-0.039 \\
(-0.07)\end{array}$ & $\begin{array}{l}-0.042 \\
(-0.08)\end{array}$ & $\begin{array}{l}-0.100 \\
(-0.24)\end{array}$ & $\begin{array}{l}-0.087 \\
(-0.17)\end{array}$ \\
\hline$E I_{i t}$ & $\begin{array}{l}9.389 \\
(1.56)\end{array}$ & $\begin{array}{c}109.929 \\
(0.70)\end{array}$ & $\begin{array}{l}9.846 \\
(1.61)\end{array}$ & $\begin{array}{l}9.389 \\
(1.56)\end{array}$ & $\begin{array}{l}-1.803 \\
(-0.60)\end{array}$ & $\begin{array}{l}9.355 \\
(1.55)\end{array}$ \\
\hline $\mathrm{GVIO}_{i t}$ & $\begin{array}{c}0.000^{* * *} \\
(6.01)\end{array}$ & $\begin{array}{c}-0.000 * * * \\
(-2.83)\end{array}$ & $\begin{array}{c}0.000 * * * \\
(6.02)\end{array}$ & $\begin{array}{c}0.000^{* * *} \\
(6.01)\end{array}$ & $\begin{array}{c}0.000 * \\
(1.77)\end{array}$ & $\begin{array}{c}0.000^{* * *} \\
(6.05)\end{array}$ \\
\hline Constant & $\begin{array}{c}51.573^{* * *} \\
(3.72)\end{array}$ & $\begin{array}{c}-3095.969 \\
* * * \\
(-6.45)\end{array}$ & $\begin{array}{c}50.132^{* * *} \\
(3.62)\end{array}$ & $\begin{array}{c}51.573^{* * *} \\
(3.72)\end{array}$ & $\begin{array}{c}28.998^{* * *} \\
(11.48)\end{array}$ & $\begin{array}{c}50.026^{* * *} \\
(3.60)\end{array}$ \\
\hline $\begin{array}{l}\text { Company- } \\
\text { fixed }\end{array}$ & YES & $\mathrm{NO}$ & YES & YES & $\mathrm{NO}$ & YES \\
\hline Time-fixed & YES & $\mathrm{NO}$ & YES & YES & $\mathrm{NO}$ & YES \\
\hline Observations & 994 & 994 & 994 & 994 & 994 & 994 \\
\hline R-squared & 0.823 & 0.311 & 0.824 & 0.823 & 0.127 & 0.824 \\
\hline
\end{tabular}

In model (2), the independent variable is green finance (GF), and the dependent variable is enterprise technology innovation (INNO-OUT, INNO-IN). From the perspective of innovation output (INNO-OUT), the regression coefficient of green finance (GF) is 0.164 , and it is significant at the $1 \%$ level. From the perspective of innovation input (INNO-IN), the regression coefficient of green finance (GF) is 0.002 , and it is significant at the $1 \%$ level. This shows that green finance has a positive effect on innovation output and innovation input of enterprises. Green finance can help enterprises to finance funds, increase sources of funds, reduce financing costs and affect the expected income structure of enterprise innovation behavior to promote enterprise output of patents and increase the proportion of $\mathrm{R} \& \mathrm{D}$ investment. The test results verify $\mathrm{H} 2 \mathrm{a}$ and $\mathrm{H} 2 \mathrm{~b}$.

In model (3), the regression coefficient of the mediating variable innovation output (INNO-OUT) is significantly negative at the level of 5\%. For every one unit increase in the number of patents granted by enterprises, the regional haze pollution concentration can be reduced by 0.002 , indicating that the more innovation output enterprises have, the more haze pollution can be alleviated. However, the regression coefficient of intermediary variable innovation input (INNO-IN) is negative, but not significant to some extent. The regression results of model (1), model (2) and model (3) show that enterprise innovation output plays a partial mediating role between green finance and haze pollution, and H3a is verified. Green finance promotes the innovation output of enterprises by helping enterprises to finance funds, effectively improving financing efficiency, reducing financing costs, improving the availability of funds and changing the income structure of enterprise innovation behavior. At the same time, with the increase in enterprise innovation output, new technologies can be applied to production and processing, where energy-consuming machinery and equipment are retrofitted to improve energy conversion rates, thus changing the structure of the consumer market to squeeze out polluting enterprises, thereby alleviating regional haze pollution. Referring to the literature of Wen and Ye (2014) on the mediating effect [58], it can be further calculated that the total effect of green finance on haze pollution enterprises is 0.018328 , the direct effect is 0.018 , and the mediating effect is 0.000328 . The mediating effect of enterprise innovation output accounts for $1.82 \%$ of the total effect. The innovation output of enterprises can only alleviate haze pollution partially. 
The results of stepwise regression method to verify the mediating effect of innovation input are not significant. In order to ensure the scientific nature of the study, the Bootstrap method is used to directly test the significance of the coefficient [58]. According to the Bootstrap test results (Table 5), it is obvious that the standardized product of INNO-IN and GF $\left(\beta_{1} \times \gamma_{2}\right)$ contains 0 at the $95 \%$ confidence level, indicating that the mediating effect of innovation investment is not significant, so the test is stopped. The above results show that the indirect effect of innovation input on regional haze pollution is not significant, and $\mathrm{H} 3 \mathrm{~b}$ is not valid.

Table 5. The result for Bootstrap test.

\begin{tabular}{ccc}
\hline & Observed Coef. & Percentile Confidence Interval \\
\hline Indirect effect & 0.00022133 & {$[-0.00000148,0.0005676]$} \\
Direct effect & 0.01279693 & {$[0.0102851,0.0156311]$} \\
\hline
\end{tabular}

The possible reasons are the following. First of all, from the perspective of enterprise R\&D investment, enterprise $R \& D$ investment includes capital resources investment and human resources investment. In order to make different researches comparable, this paper uses capital resources investment as R\&D investment, instead of human resources investment. The creativity of scientific and technological talents included in human resources often can effectively improve the technology innovation ability of enterprises, but this part of enterprise technology innovation is not calculated in the model. Secondly, only with a high investment can the R\&D of enterprises function efficiently, so as to improve the productivity and energy conversion rate, reduce the generation of pollution waste while achieving economic benefits, and achieve real energy saving and high efficiency [14]. Thirdly, R\&D investment refers to the investment of funds and human time in the process of basic research, applied research and experimental development of enterprises. The transformation of the results of funds and labour input takes time, and the results of factor input cannot occur immediately. In the short term, it may not have a direct external impact, and there is a lag, so it may not alleviate regional haze pollution.

This paper does not attribute the technological innovation of enterprises only to the innovation input, but further explores the innovation output as the independent variable that plays a direct role. Based on the above analysis, it shows that green finance will alleviate haze pollution, and enterprises in the current era of rapid development of green finance will actively respond to the call of green development for innovative output activities to help alleviate regional haze pollution. $\mathrm{H} 1, \mathrm{H} 2 \mathrm{a}, \mathrm{H} 2 \mathrm{~b}$ and $\mathrm{H} 3 \mathrm{a}$ are verified.

\subsection{Analysis of Heterogeneity}

In the context of China's dual economy, the difference in financial pressure and market competition pressure that state-owned enterprises and non-state-owned enterprises are under leads to different effects of green finance.

For the difference in financial pressure: most of non-state-owned enterprises' capital comes from the operating income on their own, while state-owned enterprises gain much support from the government. From the perspective of enterprise political relations, under the current financial system in China, there is a differentiation in the degree of enterprise financing constraints based on the nature of ownership. It is generally believed that stateowned enterprises are less constrained by financing than non-state-owned enterprises. For a long time, state-owned enterprises have been supported by the policies and funds of the government and state-owned banks. Non-state-owned enterprises tend to face stronger financing constraints on research and development (R\&D) activities because of uneven loan distributions from state-owned banks [61]. The reason may be that in order to control the risk of repayment, large banks tend to issue ordinary loans to state-owned enterprises. Therefore, the financial pressure of non-state-owned enterprises is greater than that of state-owned enterprises. However, the introduction of green finance policy aims to invest in the field of environmental protection. It mainly focuses on the environmental compliance 
of enterprises, and has less discrimination on the ownership difference of enterprises. Non-state-owned enterprises have a strong willingness to seize the financing convenience given by green finance, so as to improve their unequal financing constraints with stateowned enterprises, reduce financing costs and improve the availability of funds. They will strengthen enterprise innovation with less financial constraints, while state-owned enterprises without financial constraints are lack of motivation to respond to the call of green finance.

For the difference in market competition pressure: China's state-owned enterprises are mostly monopoly enterprises that are protected in the market. With financial advantages and government support, these industries naturally have high competitiveness. Non-stateowned enterprises are completely in a fair market competition. In order to survive in the vast economic market, non-state-owned enterprises will be more willing to constantly introduce technological innovation to earn a position for their products in the market. Therefore, the market competition pressure of non-state-owned enterprises is higher than that of state-owned enterprises.

To sum up, state-owned enterprises face less market competition pressure, so their innovation motivation is insufficient. In addition, owing to less financing constraints, their marginal contribution of green finance to innovation output is limited. However, non-stateowned enterprises are completely in a fair market competition with more financial pressure. They need to improve their technology innovation capability as much as possible to reduce production costs and seize market share. Due to the large financing constraints, the financial support brought by green finance can greatly stimulate the increase of enterprise innovation output.

In order to verify the above analysis, the samples of state-owned enterprises and nonstate-owned enterprises are grouped according to the type of ownership. Table 6 reports the regression results by enterprise ownership grouping. In the samples of non-state-owned enterprises and state-owned enterprises, the green finance (GF) in model (1) is significantly negatively correlated with regional haze pollution (PM2.5) at the 1\% level. Obviously, the influence of green finance on regional haze pollution is not related to the type of enterprise ownership, and the development of green finance can effectively inhibit the formation of regional haze pollution. In model (2), the impact of green finance on enterprise innovation output is positive, but this conclusion is only established in the sample of non-stateowned enterprises. It shows that with the development of green finance, non-state-owned enterprises will seize the innovation output to respond positively to policies, while the response of technological innovation of state-owned enterprises is obviously insufficient. In the model (3), the regression coefficient of green finance (GF) and enterprise innovation output (INNO-OUT) in the sample of non-state-owned enterprises is still significantly negative. Non-state-owned enterprises can effectively reduce regional haze pollution by actively promoting the increase of innovation output, while the enthusiasm of state-owned enterprises is relatively weak.

Table 6. Regression results of the nature of property rights.

\begin{tabular}{|c|c|c|c|c|c|c|}
\hline & \multicolumn{3}{|c|}{ State-Owned Enterprises } & \multicolumn{3}{|c|}{ Non-State-Owned Enterprises } \\
\hline & (1) & (2) & (3) & (1) & (2) & (3) \\
\hline VARIABLES & PM2.5 & $\begin{array}{l}\text { INNO- } \\
\text { OUT }_{i t}\end{array}$ & $P M 2.5_{i t}$ & PM2.5 $5_{i t}$ & $\begin{array}{l}\text { INNO- } \\
I_{\text {it }}\end{array}$ & PM2.5 $5_{i t}$ \\
\hline $\begin{array}{c}G F_{i t} \\
\text { INNO- } \\
\text { OUT }_{i t}\end{array}$ & $\begin{array}{c}-0.022 \text { *** } \\
(-6.82)\end{array}$ & $\begin{array}{l}0.217 \\
(1.39)\end{array}$ & $\begin{array}{c}-0.022 \text { *** } \\
(-7.03) \\
-0.004 \\
(-1.23)\end{array}$ & $\begin{array}{c}-0.017^{* * *} \\
(-8.97)\end{array}$ & $\begin{array}{c}0.160 * * * \\
(2.67)\end{array}$ & $\begin{array}{c}-0.017^{* * *} \\
(-8.67) \\
-0.002^{* *} \\
(-2.08)\end{array}$ \\
\hline$S I Z E_{i t}$ & $\begin{array}{l}-1.583 \\
(-0.67)\end{array}$ & $\begin{array}{c}121.343^{* * *} \\
(3.66)\end{array}$ & $\begin{array}{l}-1.236 \\
(-0.52)\end{array}$ & $\begin{array}{l}-0.207 \\
(-0.33)\end{array}$ & $\begin{array}{c}139.642^{* * *} \\
(5.69)\end{array}$ & $\begin{array}{l}-0.124 \\
(-0.20)\end{array}$ \\
\hline
\end{tabular}


Table 6. Cont.

\begin{tabular}{|c|c|c|c|c|c|c|}
\hline & \multicolumn{3}{|c|}{ State-Owned Enterprises } & \multicolumn{3}{|c|}{ Non-State-Owned Enterprises } \\
\hline & (1) & (2) & (3) & (1) & (2) & (3) \\
\hline VARIABLES & PM2.5 $5_{i t}$ & $\begin{array}{l}\text { INNO- } \\
\text { OUT }_{i t}\end{array}$ & PM2.5 & PM2.5 $5_{\text {it }}$ & $\begin{array}{c}I N N O- \\
I N_{i t}\end{array}$ & PM2.5 $5_{i t}$ \\
\hline$R O A_{i t}$ & $\begin{array}{l}-10.657 \\
(-1.16)\end{array}$ & $\begin{array}{c}808.075 \\
(1.16)\end{array}$ & $\begin{array}{l}-8.867 \\
(-0.91)\end{array}$ & $\begin{array}{l}-0.376 \\
(-0.19)\end{array}$ & $\begin{array}{c}19.830 \\
(0.33)\end{array}$ & $\begin{array}{l}-0.181 \\
(-0.09)\end{array}$ \\
\hline $\mathrm{GROW}_{i t}$ & 8.132 & 693.316 & 13.229 & 14.192 & $\underset{* * *}{-4078.436}$ & 13.491 \\
\hline & $(0.16)$ & $(0.27)$ & $(0.26)$ & $(0.63)$ & $(-3.75)$ & $(0.60)$ \\
\hline$O D R_{i t}$ & $\begin{array}{l}8.157 \\
(1.07)\end{array}$ & $\begin{array}{c}753.561 \\
(1.55)\end{array}$ & $\begin{array}{l}10.100 \\
(1.49)\end{array}$ & $\begin{array}{l}-0.456 \\
(-0.11)\end{array}$ & $\begin{array}{c}434.113^{* *} \\
(2.20)\end{array}$ & $\begin{array}{l}-1.018 \\
(-0.25)\end{array}$ \\
\hline$D U A L_{i t}$ & 0.878 & $-\underset{* *}{206.358}$ & 0.688 & 0.234 & 27.091 & 0.174 \\
\hline & $(0.89)$ & $(-2.01)$ & $(0.75)$ & $(0.49)$ & $(1.30)$ & $(0.36)$ \\
\hline$E I_{i t}$ & $\begin{array}{l}5.866 \\
(0.48)\end{array}$ & $\begin{array}{c}959.251 \\
(1.28)\end{array}$ & $\begin{array}{l}6.809 \\
(0.64)\end{array}$ & $\begin{array}{c}10.304 \\
(1.43)\end{array}$ & $\begin{array}{c}151.783 \\
(0.75)\end{array}$ & $\begin{array}{c}10.736 \\
(1.47)\end{array}$ \\
\hline $\mathrm{GVIO}_{i t}$ & $\begin{array}{l}0.000 \\
(0.75)\end{array}$ & $\begin{array}{l}-0.000 \\
(-0.94)\end{array}$ & $\begin{array}{l}0.000 \\
(0.88)\end{array}$ & $\begin{array}{c}0.000 * * * \\
(5.89)\end{array}$ & $\begin{array}{c}-0.000 * * \\
(-2.16)\end{array}$ & $\begin{array}{c}0.000 * * * * \\
(5.90)\end{array}$ \\
\hline Constant & $\begin{array}{c}86.904 \\
(1.60)\end{array}$ & $\begin{array}{c}-3034.809 \\
* * * \\
(-3.52)\end{array}$ & $\begin{array}{l}78.470 \\
(1.45)\end{array}$ & $\begin{array}{c}49.829^{* * *} \\
(3.46)\end{array}$ & $\begin{array}{c}-3186.244 \\
* * * \\
(-5.57)\end{array}$ & $\begin{array}{c}48.334^{* * *} \\
(3.36)\end{array}$ \\
\hline $\begin{array}{l}\text { Company- } \\
\text { fixed }\end{array}$ & YES & NO & YES & YES & $\mathrm{NO}$ & YES \\
\hline Time-fixed & YES & $\mathrm{NO}$ & YES & YES & $\mathrm{NO}$ & YES \\
\hline Observations & 129 & 129 & 129 & 865 & 865 & 865 \\
\hline R-squared & 0.925 & 0.333 & 0.927 & 0.786 & 0.308 & 0.787 \\
\hline
\end{tabular}

\subsection{Robustness Tests}

Two additional methods are used to test the robustness. First, given the availability of municipal data and the importance of PM10 in haze pollution in China, the dependent variable of this method is the change in PM10. PM10 covers a wider range of pollutants, and PM2.5 is only part of it. The results are shown in Table 7.

Table 7. Regression results after replacement of dependent variables.

\begin{tabular}{|c|c|c|c|}
\hline & (1) & (2) & (3) \\
\hline VARIABLES & PM10 $_{i t}$ & INNO-OUT $_{i t}$ & PM10 $_{i t}$ \\
\hline$G F_{i t}$ & $\begin{array}{c}-0.009 * * * \\
(-10.69)\end{array}$ & $\begin{array}{c}0.164^{* * *} \\
(3.02)\end{array}$ & $\begin{array}{c}-0.009 * * * * \\
(-10.27)\end{array}$ \\
\hline INNOOUT $_{i t}$ & & & $\begin{array}{l}-0.002 * \\
(-1.93)\end{array}$ \\
\hline$S I Z E_{i t}$ & $\begin{array}{l}0.478 \\
(0.76)\end{array}$ & $\begin{array}{c}136.173^{* * *} \\
(6.44)\end{array}$ & $\begin{array}{l}0.561 \\
(0.89)\end{array}$ \\
\hline$R O A_{i t}$ & $\begin{array}{l}-2.813 \\
(-1.26)\end{array}$ & $\begin{array}{r}43.235 \\
(0.70)\end{array}$ & $\begin{array}{l}-2.616 \\
(-1.17)\end{array}$ \\
\hline $\mathrm{GROW}_{i t}$ & $\begin{array}{l}10.387 \\
(0.58)\end{array}$ & $\begin{array}{c}-3266.522 * * * \\
(-3.46)\end{array}$ & $\begin{array}{l}10.229 \\
(0.57)\end{array}$ \\
\hline$O D R_{i t}$ & $\begin{array}{l}1.267 \\
(0.26)\end{array}$ & $\begin{array}{c}458.829 * * \\
(2.55)\end{array}$ & $\begin{array}{l}0.736 \\
(0.15)\end{array}$ \\
\hline
\end{tabular}


Table 7. Cont.

\begin{tabular}{cccc}
\hline & $\mathbf{( 1 )}$ & $\mathbf{( 2 )}$ & $\mathbf{( 3 )}$ \\
\hline VARIABLES & $\mathbf{P M 1 0}_{\boldsymbol{i t}}$ & INNO-OUT $_{i t}$ & PM10 $_{\boldsymbol{i t}}$ \\
\hline DUAL & 0.097 & 22.681 & 0.044 \\
& $(0.19)$ & $(1.16)$ & $(0.08)$ \\
SOE & 0.479 & -66.028 & 0.482 \\
& $(0.75)$ & $(-1.58)$ & $(0.76)$ \\
$E I_{i t}$ & -2.456 & 109.929 & -1.981 \\
GVIO $_{i t}$ & $(-0.40)$ & $(0.70)$ & $(-0.32)$ \\
& $0.000^{* * *}$ & $-0.000^{* * *}$ & $0.000^{* * *}$ \\
Constant & $(8.89)$ & $(-2.83)$ & $(8.93)$ \\
& $56.043^{* * *}$ & $-3095.969^{* * *}$ & $54.545^{* * *}$ \\
Company-fixed & $(3.89)$ & $(-6.45)$ & YES \\
Time-fixed & YES & NO & YES \\
Observations & YES & NO & 994 \\
R-squared & 994 & 994 & 0.768 \\
\hline
\end{tabular}

Notes: Robust t-statistics in parentheses. ${ }^{* * *} p<0.01,{ }^{* *} p<0.05,{ }^{*} p<0.1$.

Second, taking into account the large gap between the maximum value, 4344, and the minimum value, 0 , of innovation output, there is an extreme value in its calculation. In order to further verify the robustness of the above conclusions, the data of innovation output have been processed with $1 \%$ tailing, and the results are shown in Table 8 . As listed in the two tables, the direction and significance of all coefficients do not change greatly, showing that the findings are not affected by extreme values and the original results are robust.

Table 8. Regression results after tail processing.

\begin{tabular}{|c|c|c|c|}
\hline & (1) & (2) & (3) \\
\hline VARIABLES & PM2.5 & $I_{N N O}-O U T_{i t}$ & PM2.5 it \\
\hline$G F_{i t}$ & $\begin{array}{c}-0.018^{* * *} \\
(-12.40)\end{array}$ & $\begin{array}{c}0.104^{* * *} \\
(3.14)\end{array}$ & $\begin{array}{c}-0.018^{* * *} \\
(-12.41)\end{array}$ \\
\hline INNOOUT $_{i t}$ & & & $\begin{array}{l}-0.003 \text { ** } \\
(-2.00)\end{array}$ \\
\hline$S I Z E_{i t}$ & $\begin{array}{l}-0.239 \\
(-0.39)\end{array}$ & $\begin{array}{c}110.076^{* * *} \\
(8.14)\end{array}$ & $\begin{array}{l}-0.099 \\
(-0.16)\end{array}$ \\
\hline$R O A_{i t}$ & $\begin{array}{l}-1.267 \\
(-0.68)\end{array}$ & $\begin{array}{r}28.717 \\
(0.60)\end{array}$ & $\begin{array}{l}-0.966 \\
(-0.53)\end{array}$ \\
\hline $\mathrm{GROW}_{i t}$ & $\begin{array}{l}15.766 \\
(0.74)\end{array}$ & $\begin{array}{c}-2406.071^{* * *} \\
(-3.59)\end{array}$ & $\begin{array}{l}15.764 \\
(0.75)\end{array}$ \\
\hline$O D R_{i t}$ & $\begin{array}{l}0.201 \\
(0.06)\end{array}$ & $\begin{array}{c}391.155^{* * *} \\
(2.70)\end{array}$ & $\begin{array}{l}-0.362 \\
(-0.10)\end{array}$ \\
\hline$D U A L_{i t}$ & $\begin{array}{l}0.262 \\
(0.63)\end{array}$ & $\begin{array}{l}16.657 \\
(1.21)\end{array}$ & $\begin{array}{l}0.260 \\
(0.62)\end{array}$ \\
\hline$S O E_{i t}$ & $\begin{array}{l}-0.042 \\
(-0.08)\end{array}$ & $\begin{array}{l}-35.204 \\
(-1.24)\end{array}$ & $\begin{array}{l}-0.063 \\
(-0.12)\end{array}$ \\
\hline$E I_{i t}$ & $\begin{array}{l}9.389 \\
(1.56)\end{array}$ & $\begin{array}{c}81.082 \\
(0.62)\end{array}$ & $\begin{array}{l}9.762 \\
(1.60)\end{array}$ \\
\hline $\mathrm{GVIO}_{i t}$ & $\begin{array}{c}0.000 * * * \\
(6.01)\end{array}$ & $\begin{array}{c}-0.000^{* * *} \\
(-2.73)\end{array}$ & $\begin{array}{c}0.000 * * * \\
(6.02)\end{array}$ \\
\hline Constant & $\begin{array}{c}51.573^{* * *} \\
(3.72)\end{array}$ & $\begin{array}{c}-2497.617^{* * *} \\
(-8.01)\end{array}$ & $\begin{array}{c}48.939^{* * *} \\
(3.53)\end{array}$ \\
\hline City-fixed FE & YES & NO & YES \\
\hline Time-fixed FE & YES & $\mathrm{NO}$ & YES \\
\hline Observations & 994 & 994 & 994 \\
\hline R-squared & 0.823 & 0.370 & 0.825 \\
\hline
\end{tabular}

Notes: Robust t-statistics in parentheses. ${ }^{* *} p<0.01,{ }^{* *} p<0.05,{ }^{*} p<0.1$. 


\section{Conclusions and Implications}

\subsection{Conclusions}

Recently, the concept of environmental governance has gradually penetrated into the financial industry. Green finance has adjusted the financial policies directly linked to corporate behavior. In this background, this article constructs a theoretical framework, in which the enterprise technology innovation mediates the impact of green finance on haze pollution, provides empirical evidence based on the panel data from 2016 to 2019 at the urban level.

This paper extends our knowledge by providing empirical evidence for the impact of green finance on the urban haze pollution form a novel perspective of corporate technological innovation. First, the impacts of green finance on haze pollution and its inhibition effect are investigated in this paper. This article also explores the micro mechanism through which green finance influences haze pollution and identifies the mediating role of enterprise innovation technology from the static perspective, while the existing research mainly focuses on the macro level. Specially, the results show the partially mediating role of innovation output between green finance and haze pollution, while the mediating role of innovation input is not found in this article. The possible reasons are the incompleteness of innovation input indicators, the low value and lag of innovation input. Second, in the analysis on heterogeneity of the enterprise ownership, this article finds that state-owned enterprises do not perform as well as non-state-owned enterprises. State-owned enterprises should have born more social responsibility in environmental protection, but they face less financing constraints and market competition pressure, for the support of the government. Therefore, the innovation output of state-owned enterprises has not changed significantly under the stimulation of green finance which leads to an insignificant mediating role of innovation output of state-owned enterprises between green finance and haze pollution.

\subsection{Implications} follows.

This article also has some important policy implications which can be summarized as

On the one hand, much more attention should be paid to the mediation role of innovation technology, in order to alleviate haze pollution. Green finance affects the technological innovation output and capability of enterprises, which is an important mechanism to alleviate haze pollution. Green finance should be employed to alleviate haze pollution as 'incentive' tools and 'control' tools. From the incentive point of view, the government can broaden the channels of green financing for enterprises, increasing subsidies for qualified green projects, so that enterprises have sufficient funds for technological innovation. From the control point of view, the government may establish a set of evaluation mechanisms of the effect that green financial policy takes as soon as possible, in order to verify practical results after providing enterprises green financial support. At the same time, the government should also strengthen the disclosure standards of enterprise environmental information.

On the other hand, the government should fully consider the heterogeneity of enterprises in the formulation of green finance policies and avoid a 'one size fits all' approach. Differentiated green financial policies could truly realize the win-win effect, improving the enterprise innovation quality and controlling haze pollution. For state-owned enterprises, the government should pay special attention to their social responsibility for environmental governance, raise the threshold for state-owned enterprises to obtain green financial support, and take the quality of corporate environmental information disclosure as an important basis for them to obtain other policy support. In these ways, the government can help to strengthen the stimulating effect of green finance on state-owned enterprises. For non-state-owned enterprises, the government should further improve the qualification audit mechanism for enterprises to obtain green financial support, provide more convenient green financial services and higher green subsidies for qualified enterprises, and pay attention to the capital direction and the feedback of subsidies. 


\subsection{Research Prospects}

Firstly, limited by the availability of data, only 639 enterprises over 2016-2019 are observed in this article. Further analysis should cover more samples in longer sample period and expand the implications of the results. Due to the short time of green bond information disclosures, this paper did not identify the mediation role of technology innovation between green finance and haze pollution under the dynamic scenarios. Environmental effects of green finance in the long term may be studied in further analysis. Secondly, only green bonds are employed as the proxy of the development of urban green finance in this study, which might underestimate the impact of green finance. Thirdly, this article has focused on the mediating role of technology innovation in the relationship between green finance and haze pollution, while the other potential mediation variables may also be considered in the further studies, such as environmental regulation and industrial structure, which may lead to more useful and practical implications.

Author Contributions: Conceptualization, Y.Z., F.W. and J.W.; formal analysis, Y.Z.; investigation, Y.Z., F.W. and J.W.; data curation, Y.Z. and F.W.; writing-original draft preparation, Y.Z., F.W. and J.W.; writing - review and editing, F.W. and J.W.; All authors have read and agreed to the published version of the manuscript.

Funding: This research was funded by the National Natural Science Foundation of China (71973019), National Social Science Foundation of China (19ZDA082), and Fundamental Research Funds for the Central Universities (2019CDSKXYJG0037, 2020CDJSK02PT26, NO.2021CDJSKCG15).

Data Availability Statement: All data in this paper are from CSMAR and Wind databases.

Conflicts of Interest: The authors declare no conflict of interest.

\section{References}

1. Li, X. Scientific development and a new green deal. China Financ. Econ. Rev. 2014, 2, 2. [CrossRef]

2. Scholtens, B. Why finance should care about ecology. Trends Ecol. Evol. 2017, 32, 500-505. [CrossRef] [PubMed]

3. The Standing Committee of the National People's Congress, the Amending on the "Energy Conservation Law of the People's Republic of China". 2016. Available online: www.gov.cn/xinwen/2016-07/03/content_508771.htm (accessed on 18 December 2021).

4. Yu, C.-H.; Wu, X.; Zhang, D.; Chen, S.; Zhao, J. Demand for green finance: Resolving financing constraints on green innovation in China. Energy Policy 2021, 153, 112255. [CrossRef]

5. Zhu, X.; Zhu, S.; Huang, Y.; Huang, H. How does green finance affect urban environmental pollution in China-Take haze pollution as an example. Trop. Geogr. 2021, 41, 55-66.

6. Yu, Y.; Guo, P. Research and practice of financial industry promoting sustainable development. Environ. Prot. 2003, 12, 50-53.

7. Liu, C.; Shao, L. The construction of green financial system from the perspective of law. Shanghai Econ. $2017,2,113-117$.

8. Tang, B. Commercial banks should practice social responsibility. Banker 2013, 10, 17-18.

9. Wang, H.; Chen, B. Environmental Finance: A win-win path for financial innovation and circular economy. Shanghai Financ. 2006, 6, 29-31.

10. Salazar, J. Environmental Finance: Linking Two World. In Proceedings of the Workshop on Finance Innovations for Biodiversity Bratislava, Bratislava, Slovakia, 1-3 May 1998; pp. 2-18.

11. An, W. The connotation, mechanism and practice of green finance. Econ. Res. 2008, 5, 156-158.

12. Kim, S.B.; Cho, J.H. A study on forecasting green infrastructure construction market. KSCE J. Civ. Eng. 2014, 18, 430-443. [CrossRef]

13. He, L.Y.; Liu, R.Y.; Zhong, Z.Q.; Wang, D.Q.; Xia, Y.F. Can green financial development promote renewable energy investment efficiency? A consideration of bank credit. Renew. Energy 2019, 143, 974-984. [CrossRef]

14. Dong, T.; Li, X.; Liu, N. The impact of industrial agglomeration on haze pollution from the perspective of space: Theoretical and empirical research. Econ. Manag. 2016, 37, 29-41.

15. Li, B.; Guo, P.; Zeng, Y. The impact of haze on the availability of company debt financing: Evidence for sustainability of Chinese Listed Companies. Sustainability 2019, 11, 806. [CrossRef]

16. Li, B.; Peng, M.; Zeng, Y. Air pollution, state ownership and firm value loss. Ekoloji 2018, 27, 1167-1174.

17. Li, B.; Zhang, X.; Zeng, Y. The Impact of Air Pollution on Government Subsidies Obtained by Chinese Listed Companies. Ekoloji 2019, 28, 1947-1954.

18. Liu, Y.; Liu, M. Does smog affect the earnings management of heavily polluting companies?-An investigation based on the political cost hypothesis. Account. Res. 2015, 3, 26-33.

19. Ma, H.; Hou, G. Haze pollution, local government behavior and corporate innovation willingness-based on empirical data of listed manufacturing companies. Soft Sci. 2020, 34, 27-32. 
20. Wang, Y.; Zhao, J. "Vote with Money": The Impact of Public Environmental Concern on the Prices of Assets in Different Industries. Manag. World 2018, 34, 46-57.

21. Zhang, Y.; Liu, S.; Zeng, Y.; Li, B. Haze pollution, business performance and corporate environmental social responsibility. Environ. Manag. China 2019, 11, 39-45.

22. Leng, Y.; Du, S. Industrial structure, urbanization and smog pollution. China Sci. Technol. Forum 2015, 9, 49-55.

23. Liu, X. Dynamic evolution, spatial spillover effect of technological innovation and haze pollution in China. Energy Environ. 2018, 29, 968-988. [CrossRef]

24. Wang, F.; He, J.; Niu, Y. Role of foreign direct investment and fiscal decentralization on urban haze pollution in China. J. Environ. Manag. 2022, 305, 114287. [CrossRef]

25. Chen, Y.; Jin, G.; Kumar, N.; Shi, G. The promise of Beijing: Evaluating the impact of the 2008 Olympic Games on air quality. J. Environ. Econ. Manag. 2013, 66, 424-443. [CrossRef]

26. Zhang, T.; Liao, L. Research on the role of green finance in haze governance. Financ. Theory Teach. 2018, 5, 59-62.

27. Shahbaz, M.; Solarin, S.A.; Mahmood, H.; Arouri, M. Does financial development reduce $\mathrm{CO}_{2}$ emissions in Malaysian economy? A time series analysis. Econ. Model. 2013, 35, 145-152. [CrossRef]

28. Li, H.; Yuan, Y.; Wang, N. Evaluation on coupling and coordinated development of regional green finance and ecological environment. Stat. Decis. 2019, 35, 161-164.

29. Liu, S.Y.; Wen, S.Y. Should financial institutions be environmentally responsible in China? Facts, theory and evidence. Econ. Res. J. 2019, 54, 38-54.

30. Ren, X.; Shao, Q.; Zhong, R. Nexus between green finance, non-fossil energy use, and carbon intensity: Empirical evidence from China based on a vector error correction model. J. Clean. Prod. 2020, 277, 122844. [CrossRef]

31. Qiu, Y.; Zhang, Q.; Zhu, L.; Peng, G. Research on the impact of green finance development on innovation performance. North Financ. 2020, 6, 9-16.

32. Schumpeter, J. The Theory of Economic Development; Harvard University Press: Cambridge, MA, USA, 1932.

33. Porter, M. America's green strategy. Sci. Am. 1991, 264, 168. [CrossRef]

34. Lanoie, P.; Laurent-Lucchetti, J.; Johnstone, N.; Ambec, S. Environmental policy, innovation and performance: New insights on the Porter hypothesis. J. Econ. Manag. Strategy 2011, 20, 803-842. [CrossRef]

35. Hong, M.; Li, Z.; Drakeford, B. Do the green credit guidelines affect corporate green technology innovation? Empirical research from China. Int. J. Environ. Res. Public Health 2021, 18, 1682. [CrossRef]

36. Meng, K.; Yan, Q. Green finance and the optimization of enterprise ecological innovation input structure. Sci. Res. 2017, 35, 1886-1895.

37. Grossman, G.M.; Krueger, A.B. Environmental impacts of a North American free trade agreement. Soc. Sci. Electron. Publ. 1991, 8 , 223-250.

38. Chiou, T.-Y.; Chan, H.K.; Lettice, F.; Chung, S.H. The influence of greening the suppliers and green innovation on environmental performance and competitive advantage in Taiwan. Transp. Res. Part E Logist. Transp. Rev. 2011, 47, 822-836. [CrossRef]

39. Yuan, Y.; Rong, H. Research on the effect of environmental regulation on industrial structure adjustment-An Empirical Test Based on China's Provincial Panel Data. China's Ind. Econ. 2014, 8, 57-69.

40. Cheng, Z.; Liu, J.; Li, L. Research on the impact of industrial structure adjustment and technological progress on haze emission reduction. Soft Sci. China 2019, 1, 146-154.

41. Wei, W.; Ma, X. The optimal policy choice of energy structure adjustment and haze control China's population. Resour. Environ. 2015, 25, 6-14.

42. Lu, X.; Bai, T. How can green technology innovation effectively reduce haze pollution? Soft Sci. China 2020, 6, 174-182.

43. Lian, L. Does green credit affect the cost of debt financing-Comparative study on green enterprises and "two high" enterprises. Res. Financ. Econ. 2015, 30, 83-93.

44. Su, D.; Lian, L. Does green credit affect the investment and financing behavior of heavy polluting enterprises? Financ. Res. 2018, $12,123-137$.

45. Wang, H.; Li, M.; Tang, T. The driving factors of inter industry arbitrage of real enterprises and its impact on Innovation. China's Ind. Econ. 2016, 11, 73-89.

46. Boubakri, N.; Cosset, J.-C.; Saffar, W. The role of state and foreign owners in corporate risk-taking: Evidence from privatization. J. Financ. Econ. 2013, 108, 641-658. [CrossRef]

47. Chiu, Y.-B.; Lee, C.-C. Effects of financial development on energy consumption: The role of country risks. Energy Econ. 2020, 90, 104833. [CrossRef]

48. Fogel, K.; Morck, R.; Yeung, B. Big business stability and economic growth: Is what's good for General Motors good for America? J. Financ. Econ. 2008, 89, 83-108. [CrossRef]

49. Zhang, W.; Chiu, Y.-B. Do country risks influence carbon dioxide emissions? A non-linear perspective. Energy 2020, $206,118048$. [CrossRef]

50. He, L.; Liang, X.; Yang, X.; Zhong, Z. Can green credit promote technological innovation of environmental protection enterprises. Res. Financ. Econ. 2019, 34, 109-121.

51. Chen, Y.; Fu, J.; Yu, P. Does technological innovation reduce environmental pollution—Empirical evidence from 285 cities in China. J. Xi'an Jiaotong Univ. 2019, 39, 73-84. 
52. Dowlatabadi, H.; Oravetz, M.A. US long-term energy intensity: Backcast and projection. Energy Policy 2006, 34, 3245-3256. [CrossRef]

53. Zhang, S.; Li, Y.; Hao, Y.; Zhang, Y. Does public opinion affect air quality? Evidence based on the monthly data of 109 prefecture-level cities in China. Energy Policy 2018, 116, 299-311. [CrossRef]

54. CNEMC, China National Environmental Monitoring Centre. City Air Daily. 2021. Available online: http://www.cnemc.cn/sssj/ (accessed on 5 May 2021).

55. Meo, M.S.; Abd Karim, M.Z. The role of green finance in reducing $\mathrm{CO}_{2}$ emissions: An empirical analysis. Borsa Istanb. Rev. 2021; forthcoming.

56. Li, B.; Wang, Y.; Zeng, Y.; Cha, D. Haze pollution, innovation investment and zombie enterprise formation. Hubei Soc. Sci. 2020, 9 , 61-77.

57. Wen, Z.; Ye, B. Mediating effect analysis: Method and model development. Prog. Psychol. Sci. 2014, 22, 731-745.

58. Harris, R.D.F.; Tzavalis, E. Inference for unit roots in dynamic panels where the time dimension is fixed. J. Econom. 1999, 91, 201-226. [CrossRef]

59. Im, K.; Pesaran, M.; Shin, Y. Testing for unit roots in heterogeneous panels. J. Econom. 2003, 115, 53-74. [CrossRef]

60. Granger, C.W.J.; Newbold, P. Spurious regressions in econometrics. J. Econom. 1974, 2, 111-120. [CrossRef]

61. Wu, J. Financing constraints for R\&D in China: The role of state ownership. Appl. Econ. Lett. 2019, 26, 1162-1166. 